\title{
Phosphorus and Emerging Micro-pollutants in Surface Waters: Challenges and Prospects for Water Quality Improvements
}

\author{
Peter S. Hooda ${ }^{a^{*}}$, John Jr. Wilkinson and Helen K.G.R. Millier \\ Kingston University London, Kingston upon Thames KT1 2EE, UK, +44
}

\begin{abstract}
An oversupply of Phosphorus in water bodies accelerates growth of algae and higher forms of plant life to produce undesirable impacts on overall water quality. Phosphorus inputs to surface waters arise from a variety of point and nonpoint sources. However much of the $\mathrm{P}$ is contributed by agricultural runoff and outfall of treated (or untreated) wastewater in receiving water-bodies. Point sourced-P inputs to waters have considerably decreased in recent years, at least partly driven by regulatory requirements, e.g. the EU Water Framework Directive. This has largely been achieved by removing P from treated wastewaters at sewage treatment works (STWs). Studies have shown that introducing an additional treatment step ("P-stripping") can significantly reduce P in STW outfalls. Given P deposits are depleting, there is much interest in phosphorus recovery from wastewaters. A few STWs have already started to recover P as struvite $(\mathrm{NH} 4 \mathrm{MgPO} 4.6 \mathrm{H} 2 \mathrm{O})$ mineral - a substitute for commercially produced P-fertilizers. This requires major investment and is not economically viable at small STWs. Nonetheless it is a major breakthrough in terms of P recovery and its use.

Effluents from sewage treatment works (STW) can often contain a complex mixture of residual microcontaminants, not removed during wastewater treatment. Organic micro-pollutants have been found in rivers receiving STW effluents. Such residual contaminants have become the focus of an emerging field of water quality study and are collectively referred to as pharmaceuticals and other personal healthcare products, PPHCPs. Many of these chemicals have the ability to effect the hormonal signaling of organisms and are called endocrine disrupting compounds (EDC). Such chemicals have shown some of the most damaging biological effects in aquatic organisms. Biological effects in the aquatic environment are typically related to the development of intersex in fish. Recent research shows the use of STW practices such as upgrading from using a combined trickling filter contact process to activated sludge treatment, ozonation, membrane filtration and use of suspended biofilm reactors reduces the amount of EDCs in waste effluent. It is thus possible to remove contaminants from STW effluents, but it will not be possible without major infrastructure improvements. This paper presents the challenges and prospects of $\mathrm{P}$ and micro-organic pollutants in surface waters.
\end{abstract}

Keywords: Phosphorus, Agricultural Runoff, Sewage Effluents, Phosphorus Stripping, Emerging Micro-pollutants (EMP), Pharmaceutical and Personal Healthcare product (PPHCP), Sewage Treatment Works (STW)

\section{Introduction}

Freshwater supply has been under considerable stress in recent years, even in regions of the world previously considered with abundant water resources. Water is becoming one of the largest and most complex global challenges of the 21 st Century. It is believed that almost 2 billion people will be experiencing water scarcity by the year 2025 [1]. It is not commonly appreciated that only about $3 \%$ of this is freshwater, three quarters of which is locked up in ice. Just $0.75 \%$ is left therefore to support the entire global ecosystem and the human populace, before even considering the challenge that this fraction is not always clean, nor evenly distributed temporally or spatially [1].

${ }^{*}$ Corresponding author. Tel.: +44 2084172155

Fax: +44 20 84172155; E-mail: P.Hooda@ Kingston.ac.uk

(C) 2014 International Association for Sharing Knowledge and Sustainability

DOI: $10.5383 /$ swes.06.01.0003
There are regions of the world with a long history of water scarcity; however a growing number of new regions are now beginning to face similar challenges driven largely by growing populations and increased consumption per capita and exacerbation due to climate change [2]. Moreover, there is the growing issue of water quality degradation across the world, contributing further to freshwater scarcity [3], which is already a common occurrence in many parts of the world. The problem of freshwater availability is likely to exacerbate due to further increases in global population and the need to produce more food, and climate change will impose further stress. Thus there is much greater need to conserve, reuse and recycle water, where possible. This is however not easy and water contamination is one of the major constraints in reusing and recycling water.

Europe, particularly the European Union, is playing a leading role in using new approaches to improve water quality. A large 
number of directives have been developed and implemented to protect water resources from degradation, e.g. wastewater discharges, and water quality for fisheries, bathing, abstraction and drinking purposes. To better monitor and manage the quality of waters in the European Union and the associated legislation - the Water Framework Directive (WFD) came into force in December 2000. The WFD essentially overarches all existing water related Directives - essentially a single system of water management. It goes much beyond the requirement of managing water quality from chemical standpoints, requiring all significant waters to be restored and maintained in good ecological status by 2015 . This has much improved water quality, which is likely to improve further, driven by the requirements within the WFD.

Table 1. Major group of freshwater contaminants

\begin{tabular}{|c|c|}
\hline Contaminant Group & Main contaminants /examples \\
\hline Nutrients & Nitrogen $(\mathrm{N})$ and phosphorus $(\mathrm{P})$ \\
\hline Trace elements & $\mathrm{Cd}, \mathrm{As}, \mathrm{Hg}, \mathrm{Cr}, \mathrm{Ni}, \mathrm{Cu}, \mathrm{Zn}$ \\
\hline $\begin{array}{l}\text { Emerging } \\
\text { contaminants }\end{array}$ & $\begin{array}{l}\text { Pharmaceuticals and personal health care } \\
\text { products, fire retardants (e.g. Penta- } \\
\text {,Octa-, Deca-BDE), plasticisers (e.g. } \\
\text { BPA, BPS) }\end{array}$ \\
\hline Organic contaminants & $\begin{array}{l}\text { Poly aromatic hydrocarbons (PAHs), } \\
\text { poly chlorinated biphenyls (PCBs), } \\
\text { hydrocarbons (HCs), pesticides }\end{array}$ \\
\hline pH and acidification & $\begin{array}{l}\text { Acidic inputs from industry and acid } \\
\text { main drainage, often accompanied by } \\
\text { other contaminants (e.g. metals) }\end{array}$ \\
\hline Organic waste & $\begin{array}{lll}\text { Carbonaceous, oxygen } & \text { depleting } \\
\text { material inputs }\end{array}$ \\
\hline Suspended solids & Fine sediments \\
\hline $\begin{array}{l}\text { Microbial and protozoan } \\
\text { pathogens }\end{array}$ & $\begin{array}{l}\text { Salmonella, } \\
\text { Enteroviruses, } \\
\text { Cryptosporidium, Giardia, and other } \\
\text { disease causing micro-organisms }\end{array}$ \\
\hline
\end{tabular}

A variety of contaminants (Table 1) input into receiving waters through both point and diffused sources can present major challenges to water quality improvement. The main threats are (a) wastewater discharges - major improvements have been made e.g. removal of trace elements but there is still much scope for improvement, particularly $\mathrm{P}$ removal; b) diffused loss of $\mathrm{N}$ and $\mathrm{P}$ in agricultural runoff - not easy to control without changing land use and management practices; c) flooding and erosion can also cause major degradation of water quality - this though is only an episodic threat.

Phosphorus, being the eutrophication-limiting nutrient in most fresh and coastal waters, is perhaps most important from ecological standpoint as well as being a common water pollutant. In recent years an emerging class of microcontaminants has been detected in various water sources. These contaminants include pharmaceuticals and a large number of other health care and cleaning products that can arise in sewage systems from a variety of sources. Some may be new and others perhaps are now used in much greater amounts, so much so that they are commonly detected in sewage treatment effluents or near to the outfall points in receiving waters. In this paper, using many of our own individual case studies, we present an overview of the issues concerning excess $\mathrm{P}$ inputs to waters, and the emergence a new class of micropollutants, particularly in sewage effluents. Further, it considers the causes and the challenges that we face in improving water quality, particularly with respect to phosphorus and emerging micro-pollutants.

\section{Content}

Increased input of $\mathrm{P}$ to fresh and coastal waters has potentially serious ecological implications. While both nitrogen $(\mathrm{N})$ and $\mathrm{P}$ are implicated in aquatic eutrophication, $\mathrm{P}$ is generally considered as the eutrophication-limiting nutrient in most water-bodies. This is because most aquatic systems have sufficient $\mathrm{N}$ due to the free air-water exchange of $\mathrm{N}$ and the fixation of atmospheric nitrogen by some blue-green algae. Eutrophication and the associated ecological effects result in a general degradation in water quality. An oversupply of $\mathrm{P}$ in water bodies accelerates growth of algae and higher forms of plant life to produce undesirable impacts on overall water quality. For example, phytoplankton multiply excessively when $\mathrm{P}$ levels are high, increasing the quantity of biomass in the aquatic systems. This reduces the amount of dissolved oxygen (DO) available for other forms of aquatic life and also increases water turbidity [4]. In circumstances where excess P results in greater biomass, waters may become hypoxic as plants die off and the decomposing biomass causes further decline in the amount of DO. Phosphorus in surface waters not impacted by human activities is generally very small $(<10 \mu \mathrm{g} / \mathrm{L}$ soluble reactive phosphorus, SRP); this is generated by the natural bio-geo-cycling of phosphorus [5]. This low level of naturally occurring $\mathrm{P}$ is important and is usually sufficient to maintain "normal" biological productivity in aquatic systems.

Excess $\mathrm{P}$ in surface waters arises from various sources but major inputs include runoff from agricultural soils, domestic, farm and industrial effluents (e.g. farm and municipal sewage, silage effluents) [6]. However, $P$ in agricultural drainage is the main source, particularly in areas with no inputs from sewage sludge or other point sources of pollution [7, 8]. Run-off from manure and slurry stores and direct defecation by cattle can also contribute $\mathrm{P}$ to catchment waters but it is farmland soil, enriched with $\mathrm{P}$ due to excess applications of fertilizers and manures, which is the main source of agricultural $\mathrm{P}$ to waterbodies [9]. It is estimated that diffused $\mathrm{P}$ input via agricultural drainage accounts for about $25 \%$ of $\mathrm{P}$ in UK water-bodies [10]. Intensive fish farming, aquaculture, can also contribute $\mathrm{P}$ to water-bodies via fish wastes and uneaten fish food [11]; the extent of $\mathrm{P}$ inputs to waters from this relatively new form of farming is still the subject of investigation.

\section{Surplus phosphorus in farming systems increases}

\section{the risk of excess $P$ loss in runoff}

Phosphorus is an essential macro-nutrient and thus its application to agricultural land, particularly in areas with Pdeficient soils, improves crop production and maintains soil fertility. For most field crops, including grass, plant uptake of $\mathrm{P}$ generally varies between $10-25 \mathrm{~kg} \mathrm{P} / \mathrm{ha} / \mathrm{yr}$. However, P application rates can often far exceed this [12]. This is particularly common in livestock farming systems as most farmers take little account of the fertilizer value of manures. As a result, intensive slurry/manure applications in cattle farming systems together with fertilizer-P inputs lead to excessive $\mathrm{P}$ additions, with a consequent large amount of unutilized (surplus) P.

In farming systems where manure is applied based upon crop $\mathrm{N}$ requirement, $\mathrm{P}$ inputs can exceed plant $\mathrm{P}$ requirement several times, depending on the $\mathrm{N}$ : $\mathrm{P}$ ratio in the manures. In intensive livestock farming areas, surplus $\mathrm{P}$ can be significant, and such surplus $\mathrm{P}$ inputs will result in phosphorus 
build-up in the soil. Soil $\mathrm{P}$ content can directly influence phosphorus in runoff [13]; the build-up of soil $\mathrm{P}$ levels thus may result in increased $\mathrm{P}$ loss to water. Continual surplus $\mathrm{P}$ inputs in the long-term will gradually saturate the soil Psorption capacity. According to a study from the Netherlands, $25 \%$ saturation (25\% DSSP - degree of soil saturation with P) is considered sufficient to make the $\mathrm{P}$ loss arising from such soils unacceptable in terms of risk of water contamination with $P$ [14]. Here we summarize the findings of our work, which assessed the impact that a range of $\mathrm{P}$ application practices in farming systems has on soil-P build up and surplus $\mathrm{P}$ inputs, the potential implications of surplus $\mathrm{P}$ use, particularly the risk of excess P loss to water [15].

Table 2. Land-use and management histories of the sites studied

\begin{tabular}{|c|c|c|c|c|}
\hline $\begin{array}{l}\text { Site } \\
\text { No. }\end{array}$ & $\begin{array}{l}\text { Site name } \\
\text { and land use }\end{array}$ & P-source & $\begin{array}{l}\text { P-inputs } \\
\text { (kg/ha/y) }\end{array}$ & $\begin{array}{l}\text { Durat. } \\
\text { (yrs) }\end{array}$ \\
\hline 1 & Crichton, grassland & $\begin{array}{l}\text { TSP and/or } \\
\text { cattle slurry }\end{array}$ & $45^{\dagger}-70^{\dagger}$ & 10 \\
\hline 2 & $\begin{array}{l}\text { Craigiebuckler, } \\
\text { grass/barley }\end{array}$ & $\mathrm{TSP}+$ manure & $0-50^{\ddagger}$ & 28 \\
\hline 3 & $\begin{array}{l}\text { Ardfork, } \\
\text { grass/barley }\end{array}$ & $\mathrm{TSP}+$ manure & $0-40^{\ddagger}$ & 50 \\
\hline 4 & $\begin{array}{l}\text { Tulloch, } \\
\text { grass/barley }\end{array}$ & $\mathrm{TSP}+$ manure & $0-40^{\ddagger}$ & 50 \\
\hline 5 & $\begin{array}{l}\text { Fordoun, } \\
\text { grass/barley }\end{array}$ & $\mathrm{TSP}+$ manure & $0-40^{\ddagger}$ & 27 \\
\hline 6 & Rosemaund, cereals & $\begin{array}{l}\text { TSP or cattle } \\
\text { slurry }\end{array}$ & $0-82$ & 4 \\
\hline 7 & Gleadthorpe, cereals & $\begin{array}{l}\text { TSP or poultry } \\
\text { litter }\end{array}$ & $0-287$ & 4 \\
\hline 8 & Ropsley, cereals & TSP & $0-44$ & 13 \\
\hline 9 & $\begin{array}{l}\text { Garrionhaugh, } \\
\text { grassland }\end{array}$ & $\begin{array}{l}\text { TSP or sewage } \\
\text { sludge }\end{array}$ & $26-130$ & 8 \\
\hline 10 & $\begin{array}{l}\text { Watsonfoot, } \\
\text { grassland }\end{array}$ & $\begin{array}{l}\text { TSP or sewage } \\
\text { sludge }\end{array}$ & $26-130$ & 8 \\
\hline
\end{tabular}

$\dagger$, Additional grazing associated unquantified $\mathrm{P}$ inputs

†, Additional grazing and manure application associated unquantified $\mathrm{P}$ inputs

$\square$, Accumulated treatment period. TSP, triple superphosphate

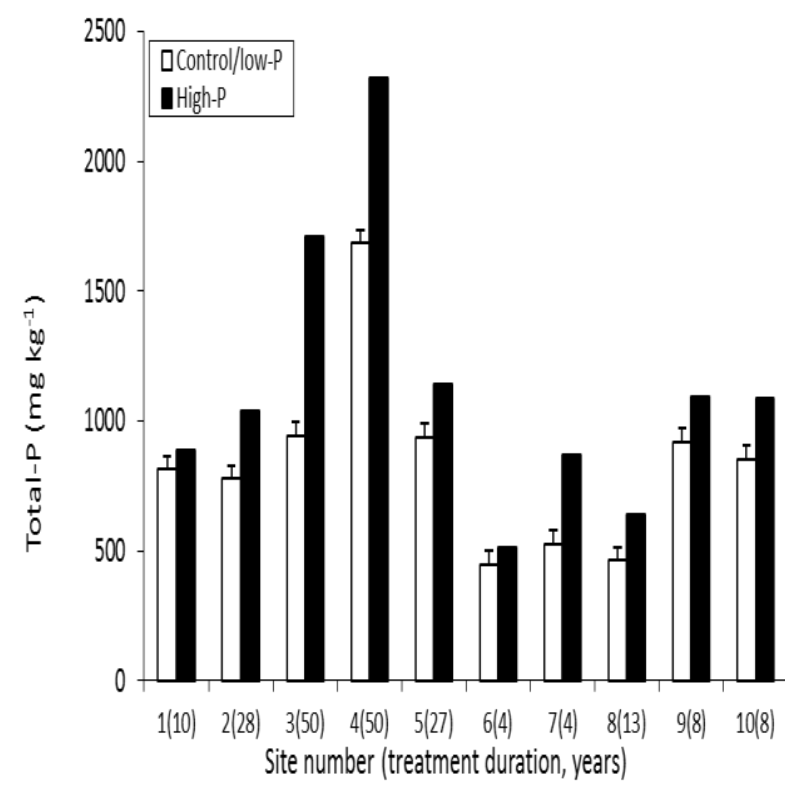

Fig. 1. The effect of $P$ inputs on total soil $P$ [15]. The values in parentheses on the $x$-axis indicate the treatment period in years. The error bars represent the least significant difference at the $5 \%$ level of significance.
A range of field sites with contrasting management histories under both grassland and arable farming systems were sampled from various locations in the UK (Table 2). Apart from the high rate of poultry litter application ( $287 \mathrm{~kg} \mathrm{P} / \mathrm{ha})$, all other manure/fertilization rates are fairly typical of those used in intensive farming systems in North America and Western Europe. Surface $(0-20 \mathrm{~cm})$ soil samples were collected in autumn or early winter, ensuring no site had any $\mathrm{P}$ inputs in the preceding 3-4 month period. While a number of soil properties and phosphorus indices were investigated and compared across the sites [15], here we mainly summarize the effect of management practices on surplus $\mathrm{P}$ inputs and how they have resulted in $\mathrm{P}$ build-up in the soils.

The total soil $\mathrm{P}$ content of the 10 sites sampled ranged from 447 to $2320 \mathrm{mg} \mathrm{P} / \mathrm{kg}$. The high rate of $\mathrm{P}$ inputs significantly $(\mathrm{p}<0.01)$ increased the soil total $\mathrm{P}$ content at each site compared to the equivalent zero-P or fields receiving lower rates of $\mathrm{P}$ inputs (Fig. 1). The increase in soil total $\mathrm{P}$ across the sites reflects the differences in P-management practices and site histories. The largest increases in total $\mathrm{P}$ occurred at sites with the longest treatment histories, and that among relatively short treatment histories occurred at a site with the largest $\mathrm{P}$ inputs (Fig. 1, Table 2).

The build-up of soil $\mathrm{P}$, according to mass balance calculations, amounted to net accumulation rates that ranged from 16.4 to $232.5 \mathrm{~kg} \mathrm{P}$ ha/yr. Accumulation rates were considerably large at sites where manure/sewage sludge applications are commonly applied (Table 2, Fig. 1). The accumulation of $\mathrm{P}$ was found directly related to its input to the soils, and the relationship showed that $\mathrm{P}$ inputs of $>24 \mathrm{~kg}$ $\mathrm{P} / \mathrm{ha} /$ year will be retained in the soils as surplus [15].

This is clear evidence of $\mathrm{P}$ inputs from long-term manure and fertilizer applications being in excess of its removal by the crops grown on these sites. This surplus $\mathrm{P}$ use in agriculture and its consequential soil accumulation as seen here (Table 2, Fig. 2) is the key factor responsible for excess loss of $\mathrm{P}$ in agricultural drainage, making agriculture as the principal cause of diffused-P inputs to catchment waters. It is thus important to realize that without addressing the problem of surplus use of $\mathrm{P}$ in farming systems, agriculture will continue to contribute $\mathrm{P}$ to surface waters. We illustrate this by comparing $\mathrm{P}$ inputs and its drainage loss from a field-scale study.

\section{Phosphorus inputs at the field-scale determine its leaching loss}

Phosphorus inputs to soils which receive intensive application of manure and are also regularly fertilized with mineral $\mathrm{P}$ often exceeding crop requirements, resulting in excessive $\mathrm{P}$ accumulation in the soil [16]. Such soils may become a significant source of excess $\mathrm{P}$ loss in surface and subsurface drainage. Lowland grassland farming systems in north-western European countries are commonly artificiallydrained. Phosphorus loss in subsurface flow may be greater from such artificially drained soils than naturally drained soils. Here, using extracts from our previous work, we demonstrate that $\mathrm{P}$ loss via subsurface field drains can be a significant source of catchment water pollution [17].

The experimental site at Dumfries, south-west Scotland, is comprised of 36 ha each under grass (Lolium perenne) and grass-white clover (Trifolium repens) mixed. The grass receives no mineral fertilizer-P whilst the grass-clover is fertilized with ca. $25 \mathrm{~kg}$ fertilizer-P/ha/yr. Both systems receive 2-3 cattle slurry applications, typically at the rate of 50 $\mathrm{m} 3 /$ ha. Over the two-year experimental period, total P (slurry + 
fertilizer) inputs averaged 44 and $67 \mathrm{~kg} \mathrm{P}$ ha/year, respectively in the grass and grass-clover pastures

Four field-size lysimeters, two on each grassland system, each with an area of 0.5 ha were established by completely isolating them from each other and from their respective management systems. Drain-flow from each plot was measured using ultrasonic electronic flow metering devices, as described elsewhere [17]. Drainage samples were collected automatically during the winter drainage period for two years, and they were analyzed for MRP (molybdate reactive phosphorus - also known as soluble reactive phosphorus, SRP) and TP following standard procedures.

The MRP and TP outputs in drain-flow for the two pastures are summarized in Figure 2. Both mean annual MRP and TP concentrations from the grass-clover pasture $(0.26$ and $0.64 \mathrm{mg} \mathrm{P} / \mathrm{L}$, respectively) were significantly larger than those from the grass $(0.16$ and $0.45 \mathrm{mg} \mathrm{P} / \mathrm{L}$, respectively). As a result, total annual losses of both MRP and TP in drainage water from the grass-clover pasture were significantly larger than those from the grass pasture (Fig. 2). The losses of $\mathrm{P}$ in subsurface-flow from the grass-clover field were significantly larger than those from the monoculture grass, reflecting the differences in $\mathrm{P}$ inputs.

These findings clearly showed that subsurface-flow from intensively managed artificially-drained pastures similar to those in the present study could be a highly significant hydrological pathway for P loss to water. It should be stressed that $\mathrm{P}$ inputs in both grass and grass-clover systems were much higher than its typical plant off take. The findings clearly suggest that $\mathrm{P}$ loss in sub-surface runoff can be controlled by not applying phosphorus in excess of crop plants requirement.

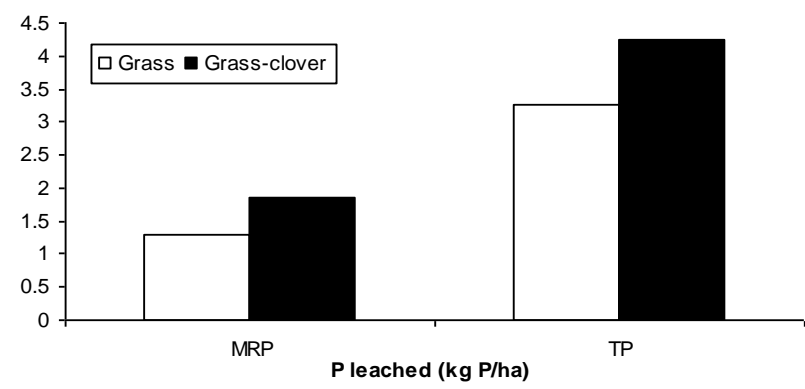

Fig. 2. Average (over two years) leaching loss of phosphorus (MRP and TP) through field drains. The total $P$ inputs in the grass and grass-clover were 44 and $67 \mathrm{~kg} P / \mathrm{ha}$, respectively [17]

\section{Phosphorus in sewage treatment works effluents}

Treated sewage wastewaters are widely recognized as a source of $\mathrm{P}$ inputs to water bodies. Human and food wastes, phosphorus based detergents and trade wastes are the major contributors of $\mathrm{P}$ to sewage [18]. The generic sewage process separates liquid and solids (primary processing), introduces biological organisms to digest organic matter (secondary processing) then either discharges the effluent or refines it using chemical or biological treatments and filtering (tertiary processing).

Unlike P from agricultural run-off where particulate $\mathrm{P}(\mathrm{PP})$ is the predominant form, the majority of PP is removed during the initial separation phase of sewage treatment leaving dissolved species in treated wastewaters [19]. In a recent study of a Thames tributary, the Hogsmill River (UK), P concentrations downstream of a major STW were an order of magnitude greater than those upstream and up to $80 \%$ of downstream TP (total P) occurred as soluble reactive phosphorus, SRP [20]. SRP concentrations in the River Bourne, also a tributary of the Thames, rose by up to $85 \%$ downstream of the STW discharge outlet (Fig. 3). Other studies of UK rivers receiving treated sewage wastewaters show high levels of dissolved P downstream of wastewaters discharge outfalls. In the River Wear, north-east England, with 15 STW upstream of the sampling point, $92 \%$ of TP occurred as TDP (total dissolved P) and $61 \%$ as SRP, and similar results were recorded for the River Cherwell at sampling points downstream of STW outfalls [21]. However, it is not just the high proportion of dissolved $\mathrm{P}$ in wastewaters that contributes to the degradation of water-bodies; the continuous nature of sewage discharge significantly impacts receiving water-bodies. Agricultural run-off is generally linked to precipitation events when in-stream dilution is high and $\mathrm{P}$ is rapidly flushed through river systems. However, sewage wastewaters discharge continuously and when the underlying river flow is reduced, treated wastewaters may contribute $80 \%$ or more of the downstream river flow in some small rivers [20]. As low river flows frequently occur during the peak plant growing season these wastewaters dominate in river systems, causing excessive plant growth, subsequent reduced levels of DO, silting and potentially fish kills [22].

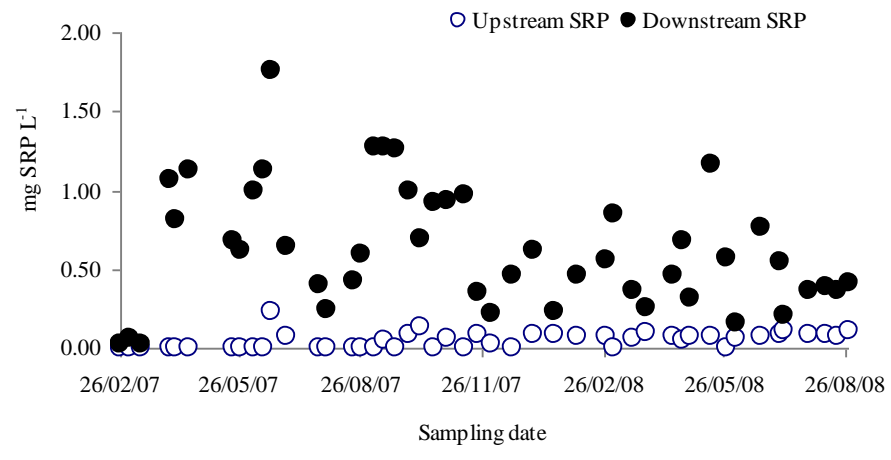

Fig. 3. River Bourne concentrations of SRP (mg P/L) up and downstream of STW discharge point [23]

\section{Treated Sewage effluents: phosphorus removal, recovery and challenges}

As a consequence of European water quality directives, wastewater treatment operators must implement P-removal processing at STW with a capacity of $>100,000$ p.e. (person equivalent) to meet discharge consents of $1 \mathrm{mg} P / \mathrm{L}$ and there is no argument that this reduces $\mathrm{P}$ concentration levels downstream of the outfalls. Improvements to SRP concentrations in rivers as a result of $\mathrm{P}$ reduction initiatives may be seen in the River Thames where SRP reduced from $1.584 \mathrm{mg} / \mathrm{L}$ in 1998 to $0.376 \mathrm{mg} / \mathrm{L}$ in 2006 [24].

The impact of the P removal at a major STW is shown in Table 3, where SRP concentrations in the Hogsmill River downstream of the wastewater outfall reduced significantly when P-removal commenced. Whilst targeting major STW facilities to reduce $\mathrm{P}$ concentrations in treated wastewaters discharges is a cost effective means of reducing $\mathrm{P}$ in water bodies, it is not a complete solution to the issue of sewage 
derived P. For example, STW facilities with $<2,000$ p.e. are only required to treat to secondary level in order to reduce biological oxygen demand (BOD) and some septic tanks may only separate liquids and solid before discharge. The impact of rural STW on rivers is likely to be disproportionate to the volume of wastewaters discharged, as receiving water-bodies tend to be smaller secondary rivers or headwaters which lack the flow or volume to dilute and/or transport wastewater effectively [4]. Targeting rural STW and septic tanks is not favoured by STW operators or the regulator, as the cost of treating small volumes of sewage waste to tertiary level is not considered cost effective.

Table 3. Flow weighted mean concentrations of $P$ in Hogsmill River upstream (U/S) and downstream (D/S) of STW and estimated contributions of P from STW (mg P/L)) [20]

\begin{tabular}{|c|c|c|c|c|c|}
\hline $\begin{array}{l}\text { Sampling } \\
\text { period }\end{array}$ & & $\begin{array}{l}\text { Species / STW } \\
\text { process }\end{array}$ & $\mathbf{U} / \mathbf{S}$ & $\mathrm{D} / \mathrm{S}$ & $\begin{array}{l}\text { STW } \\
\text { Contribution }\end{array}$ \\
\hline $\begin{array}{l}12 / 02 / 07 \\
31 / 03 / 08\end{array}$ & - & $\begin{array}{l}\text { SRP pre P- } \\
\text { stripping }\end{array}$ & 0.17 & 1.78 & 1.61 \\
\hline $\begin{array}{l}01 / 04 / 08 \\
28 / 08 / 08\end{array}$ & - & $\begin{array}{l}\text { SRP } \\
\text { stripping }\end{array}$ & 0.21 & 0.56 & 0.35 \\
\hline $\begin{array}{l}12 / 02 / 07 \\
31 / 03 / 08\end{array}$ & - & $\begin{array}{ll}\mathrm{TP} \text { pre } & \mathrm{P}- \\
\text { stripping }\end{array}$ & 0.28 & 1.99 & 1.71 \\
\hline $\begin{array}{l}01 / 04 / 08 \\
28 / 08 / 08\end{array}$ & - & TP P-stripping & 0.28 & 0.81 & 0.47 \\
\hline
\end{tabular}

It is possible that $\mathrm{P}$ will eventually become too valuable a commodity to discharge wastefully and that the long-term solution to excess $\mathrm{P}$ concentrations in receiving rivers may be driven by economics. It is widely predicted that geogenic supplies of rock phosphate, used to produce P-fertilizer, will be exhausted by the middle of the 21 st Century [25]. The issue has generated interest in developing technologies to reclaim $\mathrm{P}$ from sewage waste and pilot reclamation schemes are currently in operation world-wide. In Edmonton (Canada) a full-scale project reports $85 \%$ removal of $\mathrm{P}$ from influent which is turned into a patented slow release fertilizer [26]. Clearly recovery of $\mathrm{P}$ from sewage effluents and possibly also from sewage-sludge can offset some mineral fertilizer-P requirement and will help "recycle" phosphorus for food production. The technology exists to recover $\mathrm{P}$ from sewage effluents as Struvite $(\mathrm{NH} 4 \mathrm{MgPO} 4.6 \mathrm{H} 20)$ but it requires an onsite ammonia plant and a magnesium source. This is possible only at very large STWs, as it is economically not viable at smaller STWs. In the UK, the Severn Trent Water Company has been trialing biological nutrient recovery since 2009 and Thames Water, the UK's largest wastewater operator, is currently operating a nutrient recovery facility at Slough which is expected to yield 150,000 ton/year of slow release fertilizer (struvite containing other nutrients) [26]. Inevitably, these technologies are introduced at large STW facilities where P-stripping is already mandatory, as a means of reducing the financial impact to the operator. Therefore, it may be argued that if regulators reduce the concentrations of $\mathrm{P}$ in discharge consents for smaller STW then operators would have greater incentive to find viable means to remove $\mathrm{P}$ at all treatment works.

\section{Emerging Micro-Contaminants}

Emerging micro-contaminants (EMCs) are considered to be any compound existing in the aquatic environment, often trace levels, with the potential ability to cause ecological harm and whose presence is not routinely monitored. EDCs are vast in nature and their presence is virtually ubiquitous in the environment. Perhaps the most significant groups of EMCs include pharmaceuticals and other personal healthcare products (PPHCPs). In addition to prescription and non-prescription pharmaceutical drugs, persistent organic contaminants such as plasticisers, non-ionic surfactants in soaps and detergents, perfluorinated compounds (PFCs), and musk compounds are common PPHCPs. In recent years, PPHCP contaminants have been detected in sewage treatment work (STW) effluents, rivers and streams, ground water, oceans, drinking water and even precipitation, indicating a virtually ubiquitous presence in the aquatic environment [27-31]. Table 4 shows the concentrations of 15 commonly found PPHCP contaminants in U.S. streams and rivers as evaluated by Kolpin [27].

PPHCP environmental inputs are vast, including both point and diffuse sources. Point sources can include STW effluents and various manufacturing plants while diffuse input can arise from agricultural runoff and leachate from landfill and pasture [27, 32]. Ultimately, the sources of human and veterinary pharmaceuticals are renal (urine) and biliary (feces) excretions routed through STW facilities [33]. Many PPHCPs persist through STW processing as parent compounds while others degrade into less well-characterized metabolites [27, 29, 33]. Once environmentally present little is known regarding contaminant persistence, transport, sediment/ suspended solids uptake, degradation, and possible synergistic interactions.

Many PPHCP compounds are known environmental toxins. Pharmaceuticals in particular, being specifically designed to cause meaningful biological responses in living organisms can act on similar receptors in lower, non-target organisms. Documented ecotoxic effects of PPHCP contaminants include endocrine disruption and alterations of sex ratios in fish populations [34], larval hatch failure [35,36], anatomical abnormalities [36], and plant growth interference [37]. Concentrations of certain endocrine disrupting compounds (EDCs) are capable of creating a female-biased sex ratio and male gonadal intersex at a concentration of just 31 $\mathrm{ng} / \mathrm{L}$ [34].

As emerging micro and PPHCP contaminants are not readily removed from wastewater during treatment, limited research has been conducted investigating possible methods of contaminant removal. Among the most effective removal methods are ozonation and membrane filtration, which still may not fully eliminate PPHCP contamination [38]. However, these methods are expensive and thus out-of-reach for many STW facilities. Activated sludge treatment of wastewater has also been shown to be an effective, although not completely effective, method of PPHCP removal and is a more common STW facility upgrade than ozonation and membrane filtration [39]. Recent research has indicated that use of suspended biofilm carriers may also be an effective method of PPHCP removal [39].

Table 4. Commonly found PPHCP contaminants in US streams and rivers [27]

\begin{tabular}{lll}
\hline Compound & Compound Type & $\begin{array}{l}\text { Concentration } \\
(\mathbf{n g} / \mathbf{L})\end{array}$ \\
\hline Ibuprofen & Analgesic & $200-1000$ \\
\hline Paracetamol & Analgesic & $110-10000$ \\
\hline Cimetidine & Antacid & $74-580$ \\
\hline Ciprofloxacin & Antibiotic & $20-30$ \\
\hline Triclosan & Antibiotic & $140-2300$ \\
\hline Fluoxetine & Antidepressant & 120 \\
\hline Metformin & Antidiabetic & $110-150$ \\
\hline $\begin{array}{l}17 \alpha \text {-ethynyl } \\
\text { estradiol }\end{array}$ & Oral contraceptive & $73-831$ \\
\hline Mestranol & & \\
\hline 19 -norethisterone & Oral contraceptive & $74-404$ \\
\hline $17 \beta$-estradiol & Oral Contraceptive & $48-872$ \\
\hline
\end{tabular}




\begin{tabular}{lll}
\hline Gemfibrozil & Lipid regulator & $48-790$ \\
\hline Bisphenol-A & Plasticiser & $140-12000$ \\
\hline Triphenyl phosphate & Plasticiser & $40-220$ \\
\hline 4-Nonylphenol & $\begin{array}{l}\text { Surfactant/ } \\
\text { alkylphenol }\end{array}$ & $800-40000$ \\
\hline
\end{tabular}

\section{Conclusion}

Point-sourced P inputs have decreased considerably in the UK and other EU member states; however, they continue to contribute nutrients (including $\mathrm{P}$ ) and other pollutants, particularly in rural areas, e.g. domestic wastewater and drainage from livestock housing and yards. All point-sourced pollutant inputs are expected to decrease further to comply with the WFD requirements. Historically, discharges of treated wastewaters have contributed significant amounts of nutrients and other pollutants to receiving waters.

Advances in wastewater treatment technologies and stringent regulatory requirements have considerably reduced the pollution potential of treated wastewaters. Improved processes for the removal of $\mathrm{P}$ at STW have evidently reduced its levels in major river systems in the UK and other EU member states. However there is scope for the removal of additional quantities of $\mathrm{P}$ at large STW and this technology needs to be used at small/rural sewage treatment works as well. Recent interest in recovering $\mathrm{P}$ to use as agricultural fertilizer is expected to result in further improvements in phosphorus removal from wastewaters. However, most STWs currently are not very effective in removing/degrading EMCs, partly because of limited effluent holding time. Many of the lesspersistent EMCs are expected to degrade if final effluents holding time can be increased by constructing additional ponds. This, however, may not always be feasible due to space restrictions, particularly where STWs are situated in urban areas. Persistent EMCs, however, may require additional treatment to remove (or degrade them) before STW effluents are discharged.

Diffused-source P inputs to waters are more difficult to control as they reflect historical nutrient management practices in farming systems. Long-term excess inputs of $P$ have resulted in large amounts of its accumulation in the soils. This is particularly problematic in livestock farming areas where overlapping of mineral- and manure/slurry-P applications is common. This inevitably increases soil $\mathrm{P}$ content and thus enhances the risk of excess $\mathrm{P}$ loss in runoff. It is therefore necessary that $\mathrm{P}$ surpluses in farming systems need to be reduced so that further $\mathrm{P}$ build-up in soils can be controlled.

\section{References}

[1] Hunt, C.E., Thirsty Planet - strategies for sustainable water management, Zed Books, New York, 2004

[2] Berrittella, M., Hoekstra, A.Y., Rehdanz, K., Roson, R., and Tol, R.S.J., The economic impact of restricted water supply: A computable general equilibrium analysis, Water Research, 41, pp. 1799-1813, 2007

[3] Jury, W. A., and Vaux Jr., H. J., The Emerging Global Water Crisis: Managing Scarcity and Conflict Between Water Users, Advances in Agronomy, 95, pp. 1-76, 2007

[4] Painting, S.J., Devlin, M.J., Malcolm. S.J., Parker, E.R., Mills, D.K., Mills, C., Tett, P., Wither, A., Burt, J., Jones, R., and Winpenny, K., Assessing the impact of nutrient enrichment in estuaries: Susceptibility to eutrophication, Marine Pollution Bulletin, 55, pp. 74-90, 2007
[5] Skoulikidis, N.T., Amaxidis, Y., Bertahas, I., Laschou, S., and Gritzalis, K., Analysis of factors driving stream water composition and synthesis of management tools - a case study on small/medium Greek catchments, Science of the Total Environment, 362, pp. 205-241, 2006

[6] Ryding, S.O., Enell, M., and Wennberg, L., Swedish agricultural nonpoint source pollution: a summary of research and findings, Lake and Reservoir Management, 6, pp. $207-217,1990$

[7] Sharpley, A.N., and Withers, P.J.A., The environmentally sound management of agricultural phosphorus, Fertilizer Research, 39, pp. 133-146, 1994

[8] Sims, J.T., Simard, R.R., and Joern, B.C., Phosphorus loss in agricultural drainage: historical perspective and current research, Journal of Environmental Quality, 27, pp. $277-$ 293, 1998

[9] Hooda, P.S., Edwards, A.C., Anderson, H.A., and Miller, A., A review of catchment water quality concerns in livestock farming areas, Science of the Total Environment, 250, pp. 143-167, 2000

[10] White, P.J., and Hammond, J.P., Updating the estimate of the sources of phosphorus in U.K. waters. Final Project Report WT0701CSF, DEFRA, UK, 2007

[11] Coloso, R., King, K., Fletcher, J., Hendrix, M., Subramanyam, M., Weis, P., and Ferraris R., Phosphorus utilization in rainbow trout (Oncorhynchus mykiss) fed practical diets and its consequences on effluent phosphorus levels, Aquaculture, 220, pp. 801-820, 2003

[12] Hedley, M.J., Mortvedt, J.J., Bolan, N.S., and Syers, J.K., Phosphorus fertility management in agroecosystems. In Phosphorus in the global environment, H. Tiessen (Ed), John Wiley \& Sons Ltd., Chichester, pp, 59-92, 1995

[13] Pote, D.H., Daniel, T.C., Sharpley, A.N., Moore, P.A. Jr., Edwards, D.R., and Nichols, D.J., Relating extractable soil phosphorus to phosphorus losses in runoff, Soil Science Society of America Journal 60, pp. 855-859, 1996

[14] Breeuwsma, A., and Silva, S., Phosphorus fertilization and environmental effects in the Netherlands and the Po region (Italy). Report No. 57, Agricultural. Research Department, Wageningen, The Netherlands, 1992

[15] Hooda, P.S., Truesdale, V.W., Edwards, A.C., Withers, P.J.A., Aitken, M.N., Miller, A., and Rendell, A.R., (2001), Manuring and fertilisation effects on phosphorus accumulation in soils and potential environmental implications, Advances in Environmental Research, 5, pp. $13-21,2001$

[16] Hooda, P.S., Rendell, A.R., Edwards, A.C., Withers, P.J.W., Aitken, M.N., and Truesdale V.W., (2000), Relating soil phosphorus indices to potential phosphorus release to water, Journal of Environmental Quality, 29, pp. 1161-1171, 2000

[17] Hooda, P.S., Moynagh, M., Svoboda, I.F., Edwards, A.C., Anderson, H.A., and Sym, G., Phosphorus leaching from intensively managed grassland soils, Journal of Environmental Quality, 28, pp. 1235-1242, 1999

[18] Gruau, G., Legeas, M., Riou, C., Gallacier, E., Martineau, F., and Henin, O., The oxygen isotope composition of dissolved anthropogenic phosphates: A new tool for 
eutrophication research? Water Research, 39, pp. 232-238, 2005

[19] Mainstone, C.P., and Parr, W., Phosphorus in rivers -ecology and management, Science of the Total Environment, pp. 282-283: 25-47, 2002

[20] Millier, H.K.G.R., Hooda, P.S., and Downward, S.R., The impact of treated sewage wastewater discharges on the phosphorus levels and hydrology of two second order rivers flowing into the Thames, Journal of Environmental Monitoring, 12, pp. $1307-1314,2010$

[21] May, L., House, W.A., Bowes, M., and McEvoy, J., (2001), Seasonal export of phosphorus from a lowland catchment: upper River Cherwell in Oxfordshire, England, Science of the Total Environment, 269, pp. 117-130, 2001

[22] Hilton, J., O'Hare, M., Bowes, M.J., and Jones, J.I., How green is my river? A new paradigm of eutrophication in rivers, The Science of the Total Environment, 365, pp. 6683, 2006

[23] Millier, H.K.G.R., Evaluation of the impact of treated wastewaters discharges on river water phosphorus and metal concentrations, Unpublished $\mathrm{PhD}$ thesis, Kingston University London, UK, 2009

[24] Jarvie, H.P., Neal, C., Withers, P.J.A., Sewage-effluent phosphorus: A greater risk to river eutrophication than agricultural phosphorus? Science of the Total Environment, 360, pp. 246-253, 2006

[25] Saktaywin, W., Tsuno, H., Nagare, H., Soyama, T., and Weerapakkaroon, J., Advanced sewage treatment process with excess sludge reduction and phosphorus recovery, Water Research, 39, pp. 902-910, 2005

[26] Ostara., Introduction to Ostara Nutrient Recovery, British Columbia [http://www.ostara.com] (Accessed: 18/08/2009), 2009

[27] Kolpin, D.W., Furlong, E.T., Meyer, M.T., Thurman, E.M., Zaugg, S.D., Barber, L.B., and Buxton, H.T., Pharmaceuticals, hormones, and other organic wastewater contaminants in US streams, 1999-2000: A national reconnaissance, Environmental science \& technology, 36, pp. 1202-1211, 2002

[28] Mahmoud, M.A., Kärrman, A., Oono, S., Harada, K.H., and Koizumi, A., Polyfluorinated telomers in precipitation and surface water in an urban area of Japan, Chemosphere, 74, pp. 467-472, 2009

[29] Weigel, S., Berger, U., Jensen, E., Kallenborn, R., Thoresen, H., and Hühnerfuss, H., Determination of selected pharmaceuticals and caffeine in sewage and seawater from Troms $\varnothing /$ Norway with emphasis on ibuprofen and its metabolites, Chemosphere, 56, pp. 583-592, 2004
[30] Stackelberg, P.E., Furlong, E.T., Meyer, M.T., Zaugg, S.D., Henderson, A.K., and Reissman, D.B., Persistence of pharmaceutical compounds and other organic wastewater contaminants in a conventional drinking-water-treatment plant, Science of the Total Environment, 329, pp. 99-113, 2004

[31] López-Serna, R., Jurado, A., Vázquez-Suñé, E., Carrera, J., Petrović, M., and Barceló, D., Occurrence of 95 pharmaceuticals and transformation products in urban groundwaters underlying the metropolis of Barcelona, Spain, Environmental Pollution, 174, pp. 305-315, 2013

[32] Thiele-Bruhn, S., Pharmaceutical antibiotic compounds in soils-a review, Journal of Plant Nutrition and Soil Science, 166, pp. 145-167, 2003

[33] Jjemba, P.K., Excretion and ecotoxicity of pharmaceutical and personal care products in the environment, Ecotoxicology and Environmental Safety, 63, pp. 113-130, 2006

[34] Vajda, A.M., Barber, L.B., Gray, J.L., Lopez, E.M., Woodling, J.D., and Norris, D.O., Reproductive disruption in fish downstream from an estrogenic wastewater effluent, Environmental Science \& Technology, 42, pp. 3407-3414, 2008

[35] Ferrari, B., Paxeus, N., Giudice, R.L., Pollio, A., and Garric, J., Ecotoxicological impact of pharmaceuticals found in treated wastewaters: study of carbamazepine, clofibric acid, and diclofenac, Ecotoxicology and Environmental Safety, 55, pp. 359-370, 2003

[36] Watts, M.M., Pascoe, D., and Carroll, K., Exposure to $17 \alpha$-ethinylestradiol and bisphenol A-effects on larval moulting and mouthpart structure of Chironomus riparius, Ecotoxicology and Environmental Safety, 54, pp. 207-215, 2003

[37] Migliore, L., Brambilla, G., Casoria, P., Civitareale, C., Cozzolino, S., and Gaudio, L., Effect of sulphadimethoxine contamination on barley (Hordeum distichum L., Poaceae, Liliposida), Agriculture, Ecosystems \& Environment, 60, pp. $121-128,1996$

[38] Heberer, T., Occurrence, fate, and removal of pharmaceutical residues in the aquatic environment: a review of recent research data, Toxicology Letters, 131, pp. $5-17,2002$

[39] Falås, P., Baillon-Dhumez, A., Andersen, H.R., Ledin, A., and la Cour Jansen, J., Suspended biofilm carrier and activated sludge removal of acidic pharmaceuticals, Water Research, 46, pp. 1167-1175, 2012 